\title{
Survival of upper respiratory tract bacteria on cotton-wool swabs
}

\author{
P. W. ROSS AND H. LOUGH
}

From the Department of Bacteriology, University Medical School, Edinburgh EH8 9AG, UK

SUMMARY Plain, buffered cotton-wool swabs and albumen-coated cotton-wool swabs were pre pared with known numbers of the following: Haemophilus influenzae, Streptococcus pneumoniae, Staphylococcus aureus, corynebacteria and Escherichia coli. Swabs were plated immediately (0 hours). after loading with a $0 \cdot 1-\mathrm{ml}$ standardised inoculum; each swab was plated out four times by streaking on both halves of two plates. At 0 hours recovery rates from first platings on solid media ranged from $3.3 \%-8.9 \%$; from platings 1.4 ranges were $2.5 \%-5 \cdot 7 \%$. Both types of swabs gave similar re-o sults.

The greater the delay in plating swabs at room temperature and $4{ }^{\circ} \mathrm{C}$ the lower was the recovery rate of $\boldsymbol{H}$. influenzae and Strep. pneumoniae, though both species survived better on either kind of swab when these were held at $4^{\circ} \mathrm{C}$. There was a very small reduction in numbers of Staph. aureuse from 24 to 48 hours but the recovery rate of corynebacteria was similar over the 48-hour period, atoo both room temperature and $4^{\circ} \mathrm{C}$. Twenty-four-hour counts of $E$. coli at room temperature were approximately five times greater than at 0 hours, and at 48 hours colonies were too numerous to count. At $4^{\circ} \mathrm{C}$, however, counts of $E$. coli fell during the 48 -hour period.

In a recent study on the recovery of Streptococcus pyogenes from plain and albumen-coated cottonwool swabs, Ross (1977) showed that even when swabs loaded with standard inocula were plated immediately, only a small percentage of the initial inoculum could be recovered on solid media. Similar findings were reported by Collee et al. (1974) in studies on the recovery of anaerobic bacteria from swabs. Both studies demonstrated that the great difference between the numbers of bacteria deposited on swabs and the numbers recovered from them was because organisms were not released from the swabs and not because any toxic effect was exerted by the cotton wool.

In addition to reporting a low recovery rate on immediate plating, Ross noted a progressive fall-off in the recovery of streptococci the longer swabs were held on the bench before plating. Other authors have described similar findings and have suggested procedures to maintain viability of organisms for

Requests for reprints to: Dr P. W. Ross, Department of Bacteriology, University of Edinburgh Medical School, Teviot Place, Edinburgh EH8 9AG.

Received for publication 26 September 1977 longer periods of time (Rubbo and Benjamin, 1951 Cruickshank, 1953; Hollinger and Lindberg, 1958; Bartlett and Hughes, 1969).

Ross further noted that the viability of Strep. pyogenes was significantly enhanced when swabso were held at $4^{\circ} \mathrm{C}$ rather than at room temperatureo before being plated out, and recommended re $-\frac{3}{3}$ frigeration of swabs should any delay be anticipatedồ in sending swabs to the laboratory.

As it was not known whether the results obtainedo in the studies with streptococci would apply to other bacterial pathogens of the upper respiratory tract, the present investigation was undertaken.

\section{Material and methods}

ORGANISMS

The following strains were used: Haemophiluse influenzae (4 in number), Streptococcus pneumoniae (3), Staphylococcus aureus (6), and Escherichia coli ${ }^{-}$ (6). All were freshly isolated from pus specimens or ${ }^{\top}$ from the upper respiratory tract of patients in the Royal Infirmary, Edinburgh. In addition, eight $\varrho$ stock strains of corynebacterium were investigated. 르 These were obtained from the followings sources: C. pyogenes, C. renale, C. equi-Royal (Dick) School 
of Veterinary Studies; C. ulcerans-University of Edinburgh, Department of Bacteriology; C. xerosis -NCTC 7883; C. hofmannii-NCTC 8363; $C$. diphtheriae (gravis)-NCTC 3984; and C. diphtheriae (intermedius)-NCTC 5014.

\section{SWA BS}

Two types of commercial swabs were used. manufactured by Exogen Ltd, Dumbarton Road, Scotstoun, Glasgow. One type was made with plain, buffered, absorbent cotton-wool, and the other with albumen-coated non-absorbent cotton-wool; both were sterilised by ethylene oxide.

\section{BACTERIOLOGY}

$5-10 \%$ human blood agar plates incubated aerobically overnight at $37^{\circ} \mathrm{C}$ were used. The temperatures at which swabs were held before plating were $4^{\circ} \mathrm{C}$ or room temperature $\left(17-21^{\circ} \mathrm{C}\right)$.

Swabs were loaded with $0.02 \mathrm{ml}$ of a dilution of an overnight culture mixed with four drops $(0.08 \mathrm{ml})$ of pasteurised human saliva; parallel series were prepared using $0.08 \mathrm{ml}$ saline $(0.85 \% \mathrm{w} / \mathrm{v}$ sodium chloride) in place of the pasteurised saliva. The numbers of organisms taken up by the swabs in the $0 \cdot 1-\mathrm{ml}$ volumes varied with the groups used: $H$. influenzae $6.2 \times 10^{2}-3.0 \times 10^{3}$; Strep. pneumoniae $6.0 \times 10^{2}-4.4 \times 10^{3} ;$ Staph. aureus $6.7 \times 10^{2}-$ $7.7 \times 10^{3}$; corynebacteria $4.5 \times 10^{2}-6.0 \times 10^{3}$ E. coli $5.0 \times 10^{2}-1.5 \times 10^{3}$.

Numbers of organisms taken up by the swabs were calculated by determing surface viable counts from $10^{3}-10^{4}$ dilutions of the parent culture. These were obtained by a spread-plate procedure using a sterile glass spreader.

\section{Experiment 1}

Fifty-four tests were performed as follows: $H$. influenzae (8); Strep. pneumoniae (6); Staph. aureus (12); corynebacteria (16); and E. coli (12).

Each test required four swabs, two plain and two albumen-coated; one of each pair held a saliva preparation, the other saline. Swabs were plated immediately ( 0 hours) after loading with the $0.1 \mathrm{ml}$ standardised inoculum, and each swab was plated out four times, being streaked on both halves of two plates.

\section{Experiment 2}

Tests were performed using the same organisms as in experiment 1. In each test two plain and two albumen-coated swabs were loaded with identical inocula, one of each pair bearing a saliva preparation, the other saline. Twenty-seven tests were performed on the swabs that had been held in their containers on the bench for 24 hours; a further series was performed with swabs held for 48 hours.

Each swab was again streaked out on both halves of two plates.

\section{Experiment 3}

The organisms and methods were the same as in experiment 2 ; the only difference was that swabs were held for 24 hours and 48 hours at $4^{\circ} \mathrm{C}$ rather than at room temperature before plating.

\section{STATISTICAL METHODS}

To evaluate the effects of time, temperature, and type of swab on the recovery rate of each group of organisms data were combined and analysed as a split plot designed experiment. The main plots were the three time periods, 0,24 , and 48 hours, the subplots the two temperatures, room and $4{ }^{\circ} \mathrm{C}$, and the swabs plain and albumen-coated. Experimental blocks were the various groups of organisms; one exception to this type of analysis related to $E$. coli, which was analysed separately because of lack of data for the 0 and 24-hour periods.

Since the raw data consisted of bacterial counts square root values were used to stabilise variance in the statistical analysis.

\section{Results}

There was no significant difference between the recovery rates of organisms from plain and albumencoated swabs nor in results of those processed in saliva and in saline. The percentage recovery from first platings was greater than from platings 1-4 in all groups of organisms (Table 1). The highest isolation rate was obtained with $E$. coli $(8.9 \%$ from the plain and $8.8 \%$ from the albumen swab) and Staph. aureus ( $8.5 \%$ from both types of swab). The lowest was produced by Strep. pneumoniae $(3.8 \%$ from the plain, $4.1 \%$ from the albumen swab) and corynebacteria $(4.9 \%$ from the plain, $3.9 \%$ from the albumen swab).

Whereas the range of counts varied with individual organisms it was always greater in first platings than in platings 1-4. Upper limits were also higher in first platings because the figures obtained from platings 1-4 represented the mean of each set of observations; in most instances counts from first platings were greater than from the second, third, and fourth.

The effect of delay in plating swabs held at room temperature over a 48-hour period is shown in Table 2. There was a significant fall in the isolation rate of $\boldsymbol{H}$. influenzae and Strep. pneumoniae over this period; counts of Staph. aureus did not fall off significantly between 0 and 24 hours but did so between 24 and 48 . Those of corynebacteria were 
Table 1 Recovery of organisms on solid media from plain and albumen-coated cotton-wool swabs

\begin{tabular}{|c|c|c|c|c|c|c|c|c|c|}
\hline \multirow[t]{4}{*}{ Organism } & \multirow{4}{*}{$\begin{array}{l}\text { No. of } \\
\text { experiments }\end{array}$} & \multicolumn{8}{|l|}{ Swabs } \\
\hline & & \multicolumn{4}{|l|}{ Plain } & \multicolumn{4}{|c|}{ Albumen-coated } \\
\hline & & \multicolumn{2}{|c|}{ Mean recovery $\%$} & \multicolumn{2}{|c|}{ Range of recovery $\%$} & \multicolumn{2}{|c|}{ Mean recovery $\%$} & \multicolumn{2}{|c|}{ Range of recovery $\%$} \\
\hline & & $\begin{array}{l}\text { First } \\
\text { platings }\end{array}$ & $\begin{array}{l}\text { Platings } \\
1-4\end{array}$ & $\begin{array}{l}\text { First } \\
\text { platings }\end{array}$ & $\begin{array}{l}\text { Platings } \\
1-4\end{array}$ & $\begin{array}{l}\text { First } \\
\text { platings }\end{array}$ & $\begin{array}{l}\text { Platings } \\
I-4\end{array}$ & $\begin{array}{l}\text { First } \\
\text { Platings }\end{array}$ & $\begin{array}{l}\text { Platings } \\
1-4\end{array}$ \\
\hline$H$. influenzae & 8 & $6 \cdot 5$ & $4 \cdot 6$ & $2 \cdot 3-9 \cdot 5$ & $2 \cdot 7 \cdot 6 \cdot 3$ & $6 \cdot 7$ & $4 \cdot 4$ & $3 \cdot 3-11 \cdot 7$ & $1 \cdot 6-6 \cdot 4$ \\
\hline Strep. pneumoniae & 6 & $3 \cdot 8$ & $2 \cdot 9$ & $0 \cdot 3-8 \cdot 0$ & $0 \cdot 1-5 \cdot 7$ & $4 \cdot 1$ & $3 \cdot 3$ & $1 \cdot 0-7 \cdot 7$ & $0.9-5.9$ \\
\hline Staph. aureus & 12 & $8 \cdot 5$ & $4 \cdot 6$ & $0 \cdot 9-13 \cdot 3$ & $0 \cdot 6-9 \cdot 0$ & $8 \cdot 5$ & $4 \cdot 4$ & $1 \cdot 0-14 \cdot 2$ & $0 \cdot 6-8 \cdot 9$ \\
\hline Corynebacteria & 16 & $4 \cdot 9$ & $2 \cdot 5$ & $0 \cdot 1-12 \cdot 9$ & $0 \cdot 1 \cdot 9 \cdot 5$ & $3 \cdot 9$ & $2 \cdot 8$ & $0 \cdot 2-11 \cdot 3$ & $0 \cdot 1-7 \cdot 8$ \\
\hline E. coli & 12 & $8 \cdot 5$ & $5 \cdot 7$ & $1 \cdot 8-16 \cdot 5$ & $1 \cdot 6-10 \cdot 6$ & $8 \cdot 8$ & $5 \cdot 5$ & $2 \cdot 7-16 \cdot 0$ & $1 \cdot 7-9 \cdot 7$ \\
\hline Combined organisms & 54 & $6 \cdot 5$ & $4 \cdot 1$ & $0 \cdot 1-16 \cdot 5$ & $0 \cdot 1-10 \cdot 6$ & $6 \cdot 4$ & $4 \cdot 1$ & $0 \cdot 2-16 \cdot 0$ & $0 \cdot 1-9 \cdot 7$ \\
\hline
\end{tabular}

Table 2 Effect of time on recovery of organisms from plain and albumen-coated cotton-wool swabs held at room temperature

\begin{tabular}{|c|c|c|c|c|c|c|c|}
\hline \multirow[t]{4}{*}{ Organism } & \multirow{4}{*}{$\begin{array}{l}\text { No. of } \\
\text { experiments }\end{array}$} & \multicolumn{6}{|c|}{ Swabs } \\
\hline & & \multicolumn{3}{|c|}{ Plain } & \multicolumn{3}{|c|}{ Albumen-coated } \\
\hline & & \multicolumn{3}{|c|}{ Mean recovery $\%$ at time (hours) } & \multicolumn{3}{|c|}{ Mean recovery $\%$ at time (hours) } \\
\hline & & $O$ & 24 & 48 & 0 & 24 & 48 \\
\hline H. influenzae & 4 & 6.9 & $2 \cdot 4$ & $1 \cdot 8$ & $6 \cdot 7$ & $1 \cdot 6$ & $3 \cdot 6$ \\
\hline Strep. pneumoniae & 3 & $3 \cdot 9$ & $1 \cdot 9$ & $0 \cdot 2$ & $3 \cdot 4$ & $0 \cdot 6$ & 0 \\
\hline Staph. aureus & 6 & $8 \cdot 3$ & $7 \cdot 6$ & $5 \cdot 9$ & $8 \cdot 1$ & $6 \cdot 7$ & $5 \cdot 6$ \\
\hline Corynebacteria & 8 & $4 \cdot 2$ & $4 \cdot 1$ & $3 \cdot 6$ & $4 \cdot 7$ & $4 \cdot 2$ & $2 \cdot 6$ \\
\hline E. coli & 6 & 8.9 & $41 \cdot 5$ & TNC* & $8 \cdot 7$ & $36 \cdot 1$ & TNC* \\
\hline
\end{tabular}

*Too numerous to count

Table 3 Effect of time on recovery of organisms from plain and albumen-coated cotton-wool swabs held at $4 \mathrm{C}$

\begin{tabular}{|c|c|c|c|c|c|c|c|}
\hline \multirow[t]{4}{*}{ Organism } & \multirow{4}{*}{$\begin{array}{l}\text { No. of } \\
\text { experiments }\end{array}$} & \multicolumn{6}{|c|}{ Swabs } \\
\hline & & \multicolumn{3}{|c|}{ Plain } & \multicolumn{3}{|c|}{ Albumen-coated } \\
\hline & & \multicolumn{3}{|c|}{ Mean recovery $\%$ at time (hours) } & \multicolumn{3}{|c|}{ Mean recovery $\%$ at time (hours) } \\
\hline & & 0 & 24 & 48 & 0 & 24 & 48 \\
\hline H. influenzae & 4 & $6 \cdot 0$ & $3 \cdot 5$ & $2 \cdot 8$ & $6 \cdot 8$ & $3 \cdot 4$ & $2 \cdot 9$ \\
\hline Strep. pneumoniae & 3 & $3 \cdot 6$ & $2 \cdot 2$ & $1 \cdot 6$ & $4 \cdot 7$ & 1.8 & $1 \cdot 3$ \\
\hline Staph. aureus & 6 & $8 \cdot 7$ & $4 \cdot 8$ & $7 \cdot 7$ & $8 \cdot 9$ & $4 \cdot 7$ & $4 \cdot 5$ \\
\hline Corynebacteria & 8 & $5 \cdot 7$ & $3 \cdot 6$ & $3 \cdot 9$ & $3 \cdot 8$ & $3 \cdot 2$ & $3 \cdot 3$ \\
\hline$E$, coli & 6 & $8 \cdot 9$ & $6 \cdot 1$ & $5 \cdot 1$ & $8 \cdot 8$ & $7 \cdot 4$ & $5 \cdot 8$ \\
\hline
\end{tabular}

similar at 0,24 , and 48 hours, whereas $E$. coli showed a five-fold increase at 24 hours and at 48 hours colonies were too numerous to count.

Table 3 shows the effect of delay in plating swabs held at $4{ }^{\circ} \mathrm{C}$ over a 48 -hour period. Counts of $H$. influenzae and Strep. pneumoniae decreased over the period but not so markedly as when swabs were held at room temperature. Those of Staph. aureus and corynebacteria also showed a decrease, but there were no significant differences between those held at the two temperatures. The most marked difference in percentage recovery related to $E$. coli. Storage at $4^{\circ} \mathrm{C}$ prevented the multiplication that occurred at room temperature and produced a normal decrease in numbers over the 48-hour period.

No significant differences were shown between the percentage recovery from plain and albumen-ㅡㅡㄹ coated swabs at any of the time intervals nor in results produced by swabs processed in saliva and in saline.

Those of the above results that are reported inc the text as 'significant' are statistically significanto at a $5 \%$ level. As the calculations took up a greato deal of space they are not reproduced in this paper. Any interested person can obtain a copy of these from? the authors.

\section{Discussion}

This study set out to investigate whether the behaviour of several bacterial pathogens isolated from the upper respiratory tract from swabs was similar to 
that of Strep. pyogenes (Ross, 1977). The percentage recovery rates on solid media on immediate plating ( 0 hours) were measured and the performances of two types of cotton-wool swabs were compared. The effects of delay in plating swabs on the recovery rate and of holding swabs at room temperature and at $4^{\circ} \mathrm{C}$ on the isolation rate were assessed.

H. influenzae, Strep. pnueumoniae, Staph. aureus, and certain corynebacteria have all been isolated from infections of the upper respiratory tract, particularly otitis media and sinusitis, although they are only very rarely implicated in sore throat. Although $E$. coli has also been isolated from the upper respiratory tract it is not regarded as a typical upper respiratory tract pathogen and was included in this study to investigate the behaviour of coliforms on swabs under certain conditions. E. coli has much more relevance to wound infections, and the results presented in this paper may have an application to these.

A uniform finding in all five groups of organisms that mirrored the behaviour of Strep. pyogenes was the very low recovery rate at 0 hours. A recovery rate of less than $10 \%$ of the initial inoculum was noted for all groups and an even lower rate of less than $5 \%$ for Strep. pneumoniae and corynebacteria. Collee et al. (1974) made similar observations with anaerobic bacteria. Also, as with Strep.pyogenes, both plain and albumen-coated swabs produced similar results.

Numbers of $\boldsymbol{H}$. influenzae and Strep. pneumoniae diminished at 24 and 48 hours at both temperatures, but the reduction in numbers was much less when swabs were stored at $4^{\circ} \mathrm{C}$. Numbers of Staph. aureus did not fall significantly between 0 and 24 hours but did so between 24 and 48 hours. The storage temperatures of swabs had little effect on results. Counts of corynebacteria did not differ significantly between 0 and 48 hours, and storage temperature did not appear to influence results.

The most striking effect of temperature of storage was seen in E. coli. Only by holding swabs at $4^{\circ} \mathrm{C}$ was it possible to count colonies at 24 and 48 hours, and a reduction in numbers took place over the 48-hour period. Stored at room temperature for 24 hours, however, swabs gave isolation rates approximately five times greater than at 0 hours, and at 48 hours the colonies were too numerous to count. Similar results were obtained from both types of cotton-wool swab. The recovery rate of organisms processed in saliva was not significantly greater than that of those processed in saline, unlike the results for Strep. pyogenes (Ross 1977). Swabs held in the refrigerator remained moist over the 48-hour period.

These results indicate that in bacteriological sampling of the upper respiratory tract it makes no difference whether plain cotton-wool or albumen- coated cotton-wool swabs are used, from the point of view of either immediate or delayed recovery of the organisms. It is important, however, that these swabs are not sterilised by gamma-radiation (Mair and McSwiggan, 1965; White, 1965); the swabs used in the present series were sterilised by ethylene oxide. Furthermore, storage of swabs at $4^{\circ} \mathrm{C}$ is recommended if delay is anticipated in processing swabs. In addition to the advantages of this in regard to Strep. pyogenes, increased recovery rates of $H$. influenzae and Strep. pneumoniae were also obtained, and although the isolation rates of Staph. aureus and corynebacteria were not improved significantly, neither was any deleterious effect of storage at $4^{\circ} \mathrm{C}$ observed; and in the case of $E$. coli, and perhaps many other coliforms, refrigeration of swabs gives a more realistic picture of the numbers of organisms isolated from clinical specimens provided that an initial loss of organisms in excess of $90 \%$ is kept in mind.

In summary, a reasonable survival of bacterial pathogens from the upper respiratory tract, particularly those most relevant to infections of this region, can be expected on cotton-wool swabs for 48 hours. A greater guarantee of survival is likely, however, if swabs are refrigerated should any delay be anticipated in despatching them to the laboratory.

We are greatly indebted to $\mathrm{Mr} \mathrm{W}$. Adams, of the Medical Computing and Statistics Group, University of Edinburgh, for statistical analyses, to Professor J. Boyes for financial aid, and to Professor J. G. Collee for interest and support.

\section{References}

Bartlett, D. I., and Hughes, M. H. (1969). Bacteriological swabs. British Medical Journal, 3, 450-451.

Collee, J. G., Watt, B., Brown, R., and Johnstone, S. (1974). The recovery of anaerobic bacteria from swabs. Journal of Hygiene, 72, 339-347.

Cruickshank, R. (1953). Taking swabs. British Medical Journal, 2, 1095-1097.

Hollinger, N. F., and Lindberg, L. H. (1958). Delayed recovery of streptococci from throat swabs. American Journal of Public Health, 48, 1162-1169.

Mair, M. S., and McSwiggan, D. A. (1965). Antibacterial bacteriological swab (Letter). British Medical Journal 2, 230.

Ross, P. W. (1977). The isolation of Streptococcus pyogenes from throat swabs. Journal of Medical Microbiology, 10, 69-76.

Rubbo, S. D., and Benjamin, M. (1951). Some observations on survival of pathogenic bacteria on cotton-wool swabs: development of a new type of swab. British Medical Journal, 1, 983-987.

White, W. D. (1965). Antibacterial bacteriological swab (Letter). British Medical Journal, 2, 229-230. 